\title{
Actualization of Islamic Rules in Sharia Banking: A Review of Contemporary Issues in Jayapura, Indonesia
}

\author{
H. M. Husni T. A Ingratubun \\ Legal Study College, Umel Mandiri \\ Jl. Raya Abepura, Jayapura, Papua, 99350, Indonesia \\ Tel./Fax:+62-967-588763 E-mail: admin@stihumelmandiri.ac.id
}

Submitted: Jan 12, 2016; Reviewed: Feb 19, 2016; Accepted: Mar 5, 2016

\begin{abstract}
This article aims to determine the applicable of Islamic rules in Sharia Banking of Jayapura. The study was conducted in Jayapura City, Papua, Indonesia with purposive sampling techniques which involving over 90 respondents from two Islamic banks, Bank Muamalah Indonesia (BMI) and Bank Syariah Mandiri (BSM). The research also involved some knowledgeable informants to give rich related information. The data were analysed by using the frequency table with the descriptive analysis. Results of the research revealed that the actualization is still facing a wide range of issues. Firstly, most of the customers have not clear or deep understanding of profit-and-loss sharing system. Secondly, they also do not know what advantages they would get if they do transactions in the BMI and BMS Jayapura. Besides that, it also indicated that most of the BMI and BSM customers decided to be member of the banks because of their fanatics to their religion and they are afraid of breaking the Islamic rules.
\end{abstract}

Keywords: Bank; Islamic Law; Sharia Banking

DOI: http://dx.doi.org/10.20956/halrev.v1n1.217

\section{INTRODUCTION}

The development of Islamic Banks in Indonesia to sustain the national economic improvement in order to generate justice, togetherness, and socio-economic prosperity has been greatly supported by the creation of the Regulation Number 21 of 2008 about Islamic Banking and the Regulation Number 6 of 2009 about Bank of Indonesia. It implies to the operation of Islamic banks which has been experiencing conceptually and practically a satisfied expand, encouraging the government to keep mending the law and regulation as well as the other additional rules. In addition, the existence of Islamic banks is believed to lead this country out of economic crisis and monetary which is caused by function of bank rates of some conventional banks to maintain economic development.

Muliaman D. Hadad, the Governor Deputy of Bank Indonesia, explained that the performance of Islamic banks is brighter than that of conventional banks which have 
been basically well established. Indeed, the prospect of it is more promising with some indicators. Firstly, the potency of financial and credit affair which were 30 to $40 \%$ among the Islamic banks is higher than that of among the conventional which were only $20 \%$ in 2010 . Moreover, he mentioned that according to statistical data of Bank Indonesia issued in June 2010, the amount of fund or credit targeted reached 46, 26 trillion rupiahs. This amount increased by about $40 \%$ from 29, 71 trillion rupiah to 46,26 trillion rupiah in 2009 and 2010 respectively.

Secondly, the number of branch offices and networks keeps increasing, as noted that in June 2009 the number of the bank was only 5 banks with over 640 branch offices. Then, in December 2009, the number reached 6 banks with 711 offices. As for June 2010, it accounted for 10 different banks with around 1050 offices. In addition, from the aspect of properties and equity, it has remained soar from 39,53 trillion rupiahs in June 2009 to 48.01 trillion rupiahs in December 2009, and reaching for 61,21 trillion rupiah in June $2010 .^{1}$

Yusak Laksamana, the branch head of Mandiri Islamic Bank in Jayapura, expressed that although the population of this city is monopolized by non-moeslem society, it still can operate according to its operational standard and develops significantly, and is comparable to other banks cited out of the province. It is due to the fact that the bank has always served their customers and public satisfactorily. Even in the middle of global crisis, banks using Islamic system are not affected nationally if compared to other

Daily Cepos Papua, 27August 2010. banks operated by making use of rate system. ${ }^{2}$

However, according to Luth ${ }^{3}$ the practices of the Islamic banks have been distorted by some individuals or stake holders. He also claimed that most of the Islamic banks in Indonesia including Jayapura are simply a brand name because the Islamic management has not been adopted and practiced in line with its philosophical base, while a number of customers have not understood the overall concept of the Islamic banking.

This circumstance indicates that the stake holders only capture customers' opportunity that is looking for a good implementation of Islamic economy, including the Islamic banks, but process and management of the banks have not reflected an ideal Islamic banking system. As the consequence, the word of 'riba' which is forbidden in Islamic rules is just covered with the word of "mudharabah" or a way of profit and loss sharing. This phenomenon remains taking place continuously and they tend to recruit a lot more number of customers.

As such, the researcher claims that substance of the law of banking has not supported the implementation of Islamic banks in line with the Islamic rules. Furthermore, the researcher assumed that most of the Islamic banks have tended not to implement the Islamic rules in their operation. Therefore, the researcher intends to find out to what extent the actualisation of the Islamic banks and the implementation of Islamic rules in the products and agreement of Bank Muamalah

\footnotetext{
Daily Cepos Papua, 6 April 2010.

Muhammad. (2005). Bank Syariah. Problem dan Prospek Perkembangan di Indonesia. Yogyakarta: Graha Ilmu, pg. 43
} 
Indonesia and Bank Syariah Mandiri in Papua Province, especially Jayapura has been undertaken.

The aims of the study is to find out and understand the actualisation of the Islamic banks in Jayapura. The significances of the study are theoretically to develop knowledge of the Islamic banking in Indonesia; and practically to give contribution to economy society that is willing to recognize, know and understand about business activities of the Islamic banking.

\section{METHOD}

This research used a normative-empirical legal approach which attempted to analyzed the actualization of Islamic rules in the products and agreements of Bank Muamalah Indonesia (BMI) and Bank Syariah Mandiri (BSI) in Jayapura City. The study took place in Jayapura City, Province of Papua, with underlying consideration that while the native population of the city is dominated by non-moeslem society, but development of the Islamic banks in the city has experienced a significant increase in terms of customers' number.

The study used a purposive sampling technique which meant that the researcher selected a small number of individuals or key informants in such a way that they could help the researcher understand the phenomenon under investigation. As such, as the sample of the study, the researcher had picked up some key informants, they were: 1) two official functionary of Bank Indonesia; 2) two official senior officers of Bank Muamalah Indonesia and two of Bank Syariah mandiri, respectively; 3) 40 customers of Bank
Muamalah Indonesia and 40 of Bank Syariah Mandiri, respectively; In so doing, the number of the purposive sample was 90 .

The sources of data used in the study were categorized into two main types. The first is primary data which meant that data gathered from the samples, or the key informants. To collect data, the researcher used a guided interview and paper-andpencil method or questionnaire. The second is secondary data which is defined as data taken from either documents or files collected from the Banks relating to the study. It included, for example, a collection of regulations and the number of customers.

\section{ANALYSIS AND DISCUSSION \\ Brief History of Islamic Banking System in Indonesia}

Since 1997, economic crisis was inevitable affecting a number of conventional banks which were 240 had to experience negative speed leading an effect on liquidation, except banks operating system of Islamic rules. In November 1997, there were 16 banks facing bankruptcy, followed by other 38 banks, then continued by 55 banks. Following this factual phenomenon, some economists suggested an alternative banking system to address monetary issue faced by this country. It is a system of Islamic rules which fundamentally bases on the values of Ilahiyah.

Concerning the system of 'riba' which was comprehended as the leading force of global economic crisis in a certain range of 1923, 1930, 1940, 1980, 1990, from 1997 to 2001 and 2008 to 2009 , has motivated some Islamic intellectuals to establish a banking system which applied principles of 
Al-Quran and As-Sunnah, exempted from practice of 'riba'. ${ }^{4}$ Originally, the ideas of Islamic banking had been stated by these people since $30 \mathrm{~s}$, following a reaction of society caused by the regulation of bank rates operated in conventional bank system in 1937. Amsyaria, ${ }^{5}$ in his book of Islamic Vision to Make a Better World, says:

"Islamic teaching for development introduces a concept of Ad Dien, i.e., guidance from Allah which is more than ritual and moral principles, more than a religion in western definition. Ad Dien is a teaching from Allah for man how to live successfully here and hereafter, well coded as the holy Qur'an and Sunnah. Islamic teaching covers certainly both method of ritual-moral activities and strategies how to manage a society for the benefit of people, whenever and wherever they live".

Basir $^{6}$ said that although the idea initially did not get positive response both from community and colonist in that time, yet the situation changed after issues triggered by the regulation of bank rates emerged. Then, what had been turning a topical conversation among the Islamic intellectuals and societies was the launching of Islamic banks in Indonesia. The idea remained voiced and supported by the societies even after the independence of Indonesia was announced. It was usually spoken by the first vice President of Indonesia, Muhammad

4 Al-Jambi, A. K. (2009). Selamat Tinggal Bank Konvensional. Haramnya Bank Konvensional dan Halalnya Bank Syariah. Jakarta: Tifa Publishing House, pg: 2223.

5 Amsyaria, F. (2008). New Paradigm of National Development: Islamic Vision to Make a Better World. Jakarta: PT. RajaGrafindo Persada, pg: 11.

6 Bazir, C. (2009). Penyelesaian Sengketa Perbankan Syariah di Pengadilan Agama \& Mahkamah Syariah. Prenada Media Group: Jakarta, pg. 20
Hatta, whose educational background was economics. He classified bank rates into two groups, which are of consumptive and productive. He also explained that the rates can be unclassified as "riba" on the condition that the rate of interest must be publicly informed to society and the interest charged has to be as low as possible in spite of the productive loan.

In 1968, one of the biggest Islamic organization in Indonesia, PP Muhammadiyah, agreed that the bank rate is something which is not defined according to Islamic perspective, commending the establishment of banking system which was regulated in line with the Islamic rules. ${ }^{7}$

One of the milestones of Islamic bank development was the foundation of Islamic Development Bank (IDB) in 1975, cantered in Jedah. It is a development bank which is akin to The World Bank, Asian Development Bank, which was formed by members of Islamic Conference Organization, including Indonesia. ${ }^{8}$ In Malaysia, the root of Islamic banking is when the government established Tabung Haji or Pilgrim Management and Fund Board. The institution was established to invest the savings of local Muslims, who intend to perform Haji. Pigrim Management utilizes the concept 'Mudarabah' (profit and loss sharing), Musharikah (joint venture), and Ijarah (leasing) of financing for investment under the guidance of national Fatawah Committees of Malaysia. ${ }^{9}$

\footnotetext{
Antonio, S. M. (2009). Muhammad SAW the Super Leader, Super Manager. Jakarta: Pro LM Centre \& Tazkiah Publishing, pg: 43.

8 Karim, A. A. (2010). Bank Islam. Analisis Fiqih dan Keuangan. $4^{\text {th }}$ Editions. Jakarta: PT. RajaGrafindo Persada, pg. 65

9 Source: Avalible online from www.philadelpia.edu.jo
} 
Many other Islamic countries have established the Islamic banking system since the mid of 70s. Even in countries from minority moeslem society, such as, Philippine and Denmark, the Islamic bank has been created since 1973 and 1983 respectively. It confirmed that although Indonesia is a country with one of the biggest moeslem populations in the world, but in terms of creating Islamic financial system like Islamic banks, Indonesia is far left behind compared to other Islamic countries. ${ }^{10}$

According to Basir, ${ }^{11}$ some prevailing factors causing difficulty to establish Islamic bank in Indonesia are (1) the principles of Islamic banking have not been legitimated yet in the Banking Law No. 14 year 1967; (2) the concept of Islamic banking, in political perspective, has Islamic ideological meaning which is not the pillar of the nation; and (3) it is still questionable, indicating that investors cannot be guaranteed that they will invest their capital. However, after leading trough a range of issues, Bank Muamalat Indonesia which was formed in 1991 and has operated since 1992 becomes the first and the pioneer for the other Islamic banks in Indonesia regardless of the extent of conventional banks operating with rate system. ${ }^{12}$

\section{The Actualization of Islamic Rules in BMI and BSI}

Isa Abdurrahman as cited in Muhammad, ${ }^{13}$ eloborates the purposes of Islamic banks are:

a) to guide society to practice economic ac-

\footnotetext{
Bazir, C. Op.Cit, pg. 23.

Ibid, pg. 24

Bank Indonesia. Accessed from www.bi.go.id

13 Muhammad. (2009) Ekonomi Islam. Kontribusi Fundamentalisme Islam untuk Ekonomi Islam. Malang: Empatdua, pg. 2
}

tivities according to Islamic direction, especially banking related activities in order to avoid forbidden practices of Riba or activities of fraud because they can give negative impacts to economic development. b) to lift up the life quality of society through opening bigger business opportunities especially for group of disadvantaged community, such as, productive business for creating independence among them. c). to promote economic parity by investment so as to eradicate huge gap between the affluent (share holders) and people from low economic background. d). to cope with main social issue or poorness, which constitutes a general problem faced by most of developing coutries. e). to secure monetary economic stability of the government, such as, the effect of inflation which is caused by practices of rate system and unhealthy competition among financial bodies. f). to disappear dependency of Moeslem society on conventional banks which triggers these people not to practice their religion teaching thoroughly.

It was found over the course of the study that the products of Bank Muamalah Indonesia (BMI), before they are released to customers, should have been approved by a statement from the Board of National Shari'ah (Dewan Syariah Nasional), Board of Indonesian Ulama (Majelis Ulama Indonesia) and Bank of Indonesia (Bank Indonesia). BMI Jayapura has some banking products; they are of collecting money, such as, opening of current and deposit accounts, and Giro; and of lending money, such as, house/property credits, Pilgrim investment, and Al-Murabahah. The most selected product is the current account, house or 
property credits, and Pilgrim investment. Meanwhile, the practiced agreements of BMI are Mudharabah for the investors, Musyarakah for the property credits, and Murabahah for buy-and-sell transactions. As the head Branch of BMI Jayapura said:

"The actualization of Islamic rules in BMI Jayapura, in relation to the products and agreements, has been practiced. Agreements which are offered to either Moeslem or Non-Moeslem customers have no different condition, but what constitute concerns in this case are what benefits it gives for, and is it allowed or forbidden. BMI Jayapura is very selective in terms of financial loan which is distributed and which has to be suitable for the Islamic faith (halal). The distribution of credit in the BMI has used profit and loss system, Ijarah (leasing), and Murabahah". ${ }^{14}$

Looking at the Bank Syariah Mandiri Jayapura, Yusak Laksamana, the Head Branch, explained that the products that are offered to customers have to be in line with the direction of central BSM Jakarta, including; (1) products of collecting money, such as, Rupiah current account, USD current account, students' deposits, plan deposits, Pilgrim investment, and Giro; (2) product of finance, such as, consumptive finance, investing finance, and capital investment. It also offers some services; they are fund transfer, RTGS, Net Banking, SMS Banking, clearance, and payment point. He added that the most selected product by the customers is of students' deposits and plan deposits and the agreement applied is profit-and-loss sharing according to standard of central BSM.

Based on the Table 1, it is found that, (1) profit-and-loss system in BMI and BSM is higher than rate system which is imposed by conventional banks. The percentage of respondents from BMI and BSM saying agree is $65 \%$ and $60 \%$ respectively, and there are only $35 \%$ and $40 \%$ each disagree. In order to establish conformability, the researcher also did a deep interview to cross check the finding, and revealed that most of the customers from BMI and BSI have not clear understanding of what profit-and-loss sharing means for; and just got an explanation about

Table 1. Customers' response to operation of Islamic Banking in Jayapura

\begin{tabular}{|c|c|c|c|c|c|c|c|c|}
\hline \multirow{3}{*}{ Respondents' Opinion } & \multicolumn{8}{|c|}{ Islamic Banking } \\
\hline & \multicolumn{4}{|c|}{ Bank Muamalah Indonesia (BMI) } & \multicolumn{4}{|c|}{ Bank Syariah Mandiri (BSM) } \\
\hline & Agree & $\%$ & Disagree & $\%$ & Agree & $\%$ & Disagree & $\%$ \\
\hline $\begin{array}{l}\text { Profit-and-loss system is higher than } \\
\text { rate system }\end{array}$ & 26 & 65 & 14 & 35 & 24 & 60 & 16 & 40 \\
\hline $\begin{array}{l}\text { System of financial management is } \\
\text { more transparant and secured }\end{array}$ & 19 & 47.5 & 21 & 52.5 & 12 & 30 & 28 & 70 \\
\hline Purely Islamic system & 40 & 100 & - & 0 & 40 & 100 & - & 0 \\
\hline $\begin{array}{l}\text { Avoid Riba, but the risk is equally } \\
\text { shared }\end{array}$ & 38 & 95 & 2 & 5 & 36 & 90 & 4 & 10 \\
\hline $\begin{array}{l}\text { Give financial loan and service base } \\
\text { on customers' needs }\end{array}$ & 28 & 70 & 12 & 30 & 32 & 80 & 8 & 20 \\
\hline $\begin{array}{l}\text { Fees of Islamic banks is cheaper } \\
\text { than that of conventional banks }\end{array}$ & 22 & 55 & 18 & 45 & 24 & 60 & 16 & 40 \\
\hline
\end{tabular}

Source: Primary data.

14 Translated: Interviewed on April 21 st 2010. 
it from the bank officers and have been told that this system would give more benefit.

In terms of financial management, (2) there were $47,50 \%$ and $30 \%$ of respondents agreeing that system of financial management is more transparent and secured, meanwhile there were $52,50 \%$ and $70 \%$ of respondents disagreeing. Following up this result, the researcher made an interview with the head of Division of Supervision, Bank of Indonesia Jayapura, and claiming that all of customers' account and deposits both from Islamic and conventional banks are all secured, because of the government's guarantee through Deposit Insurance Corporation.

Moving on to the point (3), the respondents, reaching to $100 \%$, agreed that the both Islamic banks have practiced a purely Islamic system. Some respondents, based on their experience, claimed that every morning all of the officers must perform pray, express "assalamualaikum" to convey customers served, and every document of agreement is initiated with a word of "Bismillahirrahmanirahim". Moreover, the names of products and the officers' dress suits Islamic rules. For further analysis, the researcher argued that the respondents have only focused on the officers' daily activity which is done in work environment or in work office, and did not highlight on the Islamic bank activities which related to process of new account holder applications and customers' transactions.

One point to consider is that some of the BMI and BSI customers in Jayapura are non-moeslem society. It means that the officers have to be more aware of selecting new account holders and more selective in giving financial capital, especially if it would be used for illegal projects; due to the fact that some failures may cause negative effect on BMI and BSI image and reputation. The researcher has also identified that the human resource working in the Islamic banks turned an issue because most of the employees do not have relevant qualification and competence, while working targets determined by the manager of the banks are extraordinarily high to which applicants have to be recruited as many as possible. As a consequence, the officers would only hunt the target for rewarding and promised incentives and not concern whether or not the business of customers are allowed.

Looking at the question 4, around 95\% and $90 \%$ of respondents from BMI and BSI agreed that the banks operate to avoid riba yet the risk is equally shouldered; otherwise, there was only $5 \%$ and $10 \%$ of respondents respectively disagreed. One of the informant designated from the Board of Indonesian Ulamah saying:

"The group of respondents falling in with the question has given a strong support to both BMI and BSI in running their business of Islamic banking in Jayapura. Now it depends on the bank management system, especially associating with the target handed to their officers, we don't want they will break the rules of Islamic to reach their targets." 15

Moving on to the respondents' answer dealing with financial loan and service based on customers' needs, it mentioned that $70 \%$ and $80 \%$ of respondents from BMI and BSI said agree, while it was $30 \%$ and

15 Translated: Interviewed on January $31^{\text {st, }} 2012$. 
$20 \%$ of respondents respectively stating disagree. One of account holders of the BMI commented that:

"As an entrepreneur, we feel that it has met our needs in this province, somehow there are some issues, such as, some of us do not really understand about system of profit-and-loss sharing, so that we are doubtful to use this facility. Moreover, lack of socialisation or information provided by the Islamic banks to most of businessmen through personal and organizational meetings has become another obstacle." 16

In terms of cheaper fees imposed to customers, it accounted for $55 \%$ and $60 \%$ of the respondents which said agree, while there were $45 \%$ and $40 \%$ saying disagree. It means that the fee which was obliged to customers in the Islamic banks does not differ extensively from that of conventional banks. However, a random customer of the Islamic bank assumed that since 2009, the first time she joined the BSM Jayapura, she never felt that the fee of the BSM Jayapura is cheaper than that of conventional banks. She gave an example, if she proposed a loan fund to the head of the BSM in order to get financial assistance; she was directed to a designated notarist to manage every required documents, such as, property certificate for guarantee, which cost some amount of money. As such, she claimed that there is no difference fee imposed to costumers between Syariah Banks and conventional banks.

A similar response conveyed by another customer, he said that he although has become a member of BMI Jayapura since 2008, he never felt that the administration fee imposed by the bank to customers was cheaper than that of conventional banks. He said so, because he has also managed and got financial loan from the conventional banks, including Bank Panin, BRI, and Bank Mandiri. His saving account was auto debited every month to pay the administration fee.

\section{CONCLUSION}

In accordance with islamic rules in sharia banking of Jayapura, that majority of the Islamic banks' customers are moeslem society. Most of them have not clear or deep understanding of profit-and-loss sharing system and do not know what advantages they would get if they do transactions in the BMI and BMS Jayapura. The researcher claimed that most of the BMI and BMS customers decided to be member of the banks because of their fanatics to their religion and they are afraid of breaking the Islamic rules.

The Islamic Banks have been very accommodative, given positive contribution to help society especially in Jayapura city as well as have been an active partner for community in doing financial transactions so as to accelerate economic development in Indonesia. For further research, it can analyse the implementation of of Islamic rules in the products and agreements of Bank Muamalah Indonesia (BMI) and Bank Syariah Mandiri (BSI) in Jayapura City, Papua, Indonesia.

\section{REFERENCES}

Al-Jambi, A. K. (2009). Selamat Tinggal Bank Konvensional. Haramnya Bank Konvensional dan Halalnya Bank Syariah. Jakarta: Tifa Publishing House. 
Amsyaria, F. (2008). New Paradigm of National Development: Islamic Vision to Make a Better World. Jakarta: PT. RajaGrafindo Persada.

Antonio, S. M. (2009). Muhammad SAW the Super Leader, Super Manager. Jakarta: Pro LM Centre \& Tazkiah Publishing. Bazir, C. (2009). Penyelesaian Sengketa Perbankan Syariah di Pengadilan Agama \& Mahkamah Syariah. Jakarta: Prenada Media Group.

Daily Cepos Papua, 27August 2010.

Daily Cepos Papua, 6 April 2010.
Karim, A. A. (2010). Bank Islam. Analisis Fiqih dan Keuangan. $4^{\text {th }}$ Editions. Jakarta: PT. RajaGrafindo Persada.

Muhammad. (2005). Bank Syariah. Problem dan Prospek Perkembangan di Indonesia. Yogyakarta: Graha Ilmu.

Muhammad. (2009) Ekonomi Islam. Kontribusi Fundamentalisme Islam untuk Ekonomi Islam. Malang: Empatdua.

Perwataatmadja, A. K. \& Tanjung, H. (2007). Bank Syariah. Teori, praktik, dan Peranannya. Jakarta: Celestial Publishing. 